\title{
Revitalisasi Cagar Budaya untuk Pengembangan Pariwisata di Kawasan van Dering Serukam
}

\section{Revitalizing Cultural Heritage for Tourism Development in the van Dering Serukam Area}

\author{
Sabinus Beni1) a)*, Blasius Manggu') b), Yosua Damas Sadewo') a), Thomas Aquino') a) \\ 1) Prodi Kewirausahaan, Institut Shanti Bhuana \\ a) Jl. Bukit Karmel No.1 Bengkayang. 79211. Kalimantan Barat \\ 2)Prodi Manajemen, Institut Shanti Bhuana \\ b) Jl. Bukit Karmel No.1 Bengkayang. 79211. Kalimantan Barat \\ *Email: sabinusbeni@gmail.com
}

\begin{abstract}
The hilltop is located at van Dering Hill commonly named van Dering Fortress by the nearest communities in Serukam Hamlet, Pasti Jaya Village, Samalatan Sub-district, Bengkayang District. This research aimed to describe the revitalization process of van Dering Fortress. This study used a qualitative approach. It carried on in the van Dering Serukam tourism area. Primary data were collected through interviews with community elders, village leader, and sub-district head. Next, the data were analyzed qualitatively. This study resulted that van Dering Fortress was broken about 90\%. It happened for a long time since the Dutch have not left Serukam yet. Both local and central government have not yet to pay attention to van Dering Hilltop as a cultural heritage. The landowner of the location of Dutch Hilltop finally built a house on the foothill. This cultural heritage abandonment caused the loss of historical asset during Dutch colonization. Van Dering revitalization was assumed to bring positive impacts for tourism development in Bengkayang District. Then, it could increase the local government income, so that it can support economic growth and local development.
\end{abstract}

Keywords: cultural heritage, revitalization, serukam, van Dering fortress

\begin{abstract}
ABSTRAK
Pos intai Belanda yang terletak di Bukit Van Dering biasa disebut Benteng van Dering oleh masyarakat Dusun Serukam merupakan salah satu peninggalan sejarah yang terletak di Desa Pasti Jaya, Kecamatan Samalatan, Kabupaten Bengkayang. Tujuan penelitian adalah menggambarkan upaya revitalisasi Benteng van Dering. Penelitian menggunakan pendekatan kualitatif dan dilakukan di kawasan wisata van Dering Serukam. Data primer diperoleh melalui wawancara dengan para tetua adat, kepala desa, dan camat. Data yang diperoleh selanjutnya dianalisis secara kualitatif. Hasil penelitian menunjukkan bahwa cagar budaya Benteng van Dering berada pada kondisi rusak. Kondisi tersebut terjadi sudah sejak lama, dimana 90\% Benteng van Dering sudah hancur, bahkan sebelum Belanda meninggalkan Dusun Serukam. Pemerintah, baik pusat maupun daerah belum memberikan perhatian terhadap revitalisasi Benteng van Dering sebagai kawasan cagar budaya sejarah. Pemilik lahan tempat berlokasinya pos intai Belanda pada akhirnya membangun rumah di bawah kaki bukit. Apabila kondisi tersebut terus terjadi, dapat berdampak hilangnya jejak keberadaan aset bersejarah periode penjajahan Belanda. Revitalisasi Benteng van Dering di Bukit van Dering diharapkan dapat memberikan dampak positif bagi perkembangan pariwisata di Kabupaten Bengkayang. Selanjutnya, hal tersebut dapat meningkatkan pendapatan asli daerah sehingga mendukung pembangunan dan pertumbuhan ekonomi.
\end{abstract}

Kata kunci : cagar budaya, revitalisasi, serukam, benteng van Dering

\section{PENDAHULUAN}

Kabupaten Bengkayang pada awalnya merupakan bagian wilayah administratif Kabupaten Sambas. Kabupaten Bengkayang berdiri pada tanggal 27 April 1999 sebagai hasil dari pemberlakuan otonomi daerah. Kabupaten Bengkayang didiami oleh berbagai etnis, antara lain etnis Dayak (etnis asli Pulau Borneo), Tionghoa, Melayu, Jawa, Nusa Tenggara, dan beberapa etnis minoritas lain. Etnis Tionghoa 
datang ke Kabupaten Bengkayang sekitar tahun 1600 sebagai bagian dari upaya masyarakat Cina untuk mendapatkan kehidupan yang layak sebagai penambang emas. Salah satu bukti sejarah peninggalan etnis Tionghoa di masa lampau adalah tiang bendera Cina di Kecamatan Monterado.

Selain peninggalan etnis Tionghoa, peninggalan sejarah masa penjajahan Belanda juga dapat ditemukan di beberapa kecamatan, seperti Kecamatan Bengkayang, Kecamatan Sungai Betung, dan Kecamatan Samalantan. Salah satu peninggalan Belanda terdapat di Dusun Serukam, Desa Pasti Jaya, Kecamatan Samalantan adalah sebuah pos intai. Sebagian masyarakat sekitar menyebut pos intai tersebut sebagai benteng Belanda atau benteng Jepang. Sementara itu, sebagian yang lain menyebut cagar budaya tersebut sebagai mendereng, mendering pendereng, atau pandereng. Pos intai tersebut pada awalnya berjumlah empat buah, namun hanya tersisa 1 buah yang terletak di Bukit van Dering. Peninggalan Belanda lainnya berada di Kecamatan Monterado berupa salib raksasa yang terletak di tepi Danau Taipi.

Pengkajian terhadap peninggalan sejarah perlu dilakukan sebagai sumber informasi untuk pelestarian cagar budaya dan pengembangan pariwisata (Hapsari, Usman, \& Ayustia, 2021). Selanjutnya pelestarian cagar budaya diharapkan dapat meningkatkan pengetahuan dan kesadaran masyarakat terutama generasi muda tentang sejarah. Bukit van Dering, atau yang lebih dikenal dengan nama van Dering terletak di Dusun Serukam, Desa Pasti Jaya, Kecamatan Samalantan, Kabupaten Bengkayang. Van Dering berasal dari nama seorang jenderal Belanda yang dikenal sangat kejam pada masa penjajahan.

Selanjutnya, van Dering dijadikan nama jalan di sebuah tikungan dari jalan berkelokkelok yang menghubungkan Kabupaten Bengkayang dan Kota Singkawang. Jalan tersebut terletak di sebuah bukit yang sangat asri serta memiliki pemandangan yang menakjubkan. Terdapat Rumah Sakit Bethesda milik yayasan Protestan yang cukup terkenal hingga akhir tahun 2000. Rumah sakit tersebut cukup terkenal karena memiliki pelayanan berkualitas dan menyediakan layanan misionaris hingga pelosok kabupaten. Kondisi tersebut menjadikan Bukit van Dering lebih dikenal oleh para pengguna jalan. Saat ini, tikungan di Bukit van Dering tersebut menjadi tempat favorit untuk berswafoto oleh para remaja Bengkayang dan Singkawang. Terdapat berbagai cerita mistis yang diyakini oleh masyarakat Bukit van Dering. Sebagian masyarakat memercayai kawasan tersebut memiliki aura negatif.

Sebagian masyarakat sekitar belum mengetahui sejarah kelam Bukit van Dering. Jalanan yang melewati Bukit van Dering berasal dari tumpukan mayat-mayat masyarakat Dayak. Terdapat bekas benteng pertahanan Hindia Belanda di Kawasan van Dering yang didirikan periode tahun 1939 hingga 1942. Benteng tersebut digunakan oleh pasukan Belanda untuk mengintai pasukan Jepang. Selain itu, benteng tersebut juga menjadi pusat militer Belanda di Bengkayang. Benteng dibangun di setiap puncak bukit sehingga secara keseluruhan terdapat empat benteng. Tiga benteng telah dihancurkan oleh pasukan Belanda saat hendak meninggalkan Bengkayang hingga tersisa satu benteng.

Struktur bangunan Benteng van Dering terlihat unik di beberapa bagian. Terdapat sumur yang cukup untuk satu orang saja. Bagian atas sumur ditutup dengan cor semen yang cukup tebal, sementara di bagian depan terdapat lubang intai berbentuk persegi panjang. Tinggi benteng sekitar tinggi orang dewasa berdiri. Terdapat parit yang berada di antara benteng-benteng tersebut. Parit tersebut digunakan sebagai tempat persembunyian pasukan Belanda.

Kawasan van Dering saat ini menjadi semakin ramai karena makin banyak dikenal orang. Namun demikian, kondisi bangunan pos intai cukup memprihatinkan dengan kerusakan cukup berat. Oleh karena itu, dibutuhkan perhatian dari seluruh komponen, baik dari masyarakat setempat (Pemerintah Desa Pasti Jaya dan pemilik tanah lokasi pos intai), Pemerintah Daerah Kabupaten Bengkayang, serta pemerintah pusat. Perhatian tersebut dapat diwujudkan melalui upaya revitalisasi bangunan pos intai serta perbaikan infrastuktur pendukung agar masyarakat mudah mengunjungi lokasi (Usman \& Hapsari, 2020). Revitalisasi juga seharusnya diikuti upaya penetapan Bukit van Dering sebagai kawasan yang dilindungi untuk menjaga kelestariannya 
sehingga mendukung upaya pengembangan destinasi wisata (Purnasari \& Sadewo, 2019).

Pengembangan dan pengelolaan Bukit van Dering berpotensi meningkatkan Pendapatan Asli Daerah (PAD) ataupun Pendapatan Asli Daerah Desa (PAD Desa), utamanya Desa Serukam dan sekitar Bukit van Dering (Erbito \& Hapsari, 2019). Hal tersebut dapat terwujud melalui kegiatan pariwisata maupun aktivitas ekonomi yang melibatkan masyarakat sekitar. Selain itu, terdapat kawasan wisata Bukit Rancutn di Kecamatan Betung yang menawarkan pemandangan alam yang indah. Kedua destinasi wisata tersebut dapat diintegrasikan sehingga dapat menarik lebih banyak wisatawan (Sadewo \& Purnasari, 2019).

Bukit van Dering atau van Dering Hill, oleh masyarakat sekitar disebut dengan pendereng atau mendereng adalah sebuah jalan berkelok. Jalan tersebut merupakan buatan Pemerintah Kolonial Belanda. Masyarakat setempat meyakini Bukit van Dering menyimpan berbagai cerita misteri. Sebagian besar orang yang melewati bukit tersebut menyatakan merasakan aura negatif.

Kondisi Benteng van Dering saat ini terlihat tidak terpelihara dengan baik. Masyarakat sekitar maupun Pemerintah Daerah Kabupaten Bengkayang tampaknya belum melakukan upaya pemugaran maupun revitalisasi Benteng van Dering. Sebagian masyarakat bahkan tidak mengetahui keberadaan benteng tersebut. Selain itu, penunjuk arah yang menjadi penanda keberadaan pos intai juga tidak ditemukan. Reruntuhan beberapa pos intai dapat ditemukan di sepanjang Perbukitan van Dering. Parit yang menghubungkan antarpos juga sudah tidak terlihat dan tertutup semak belukar. Terdapat dugaan bahwa beberapa pos tersebut sengaja dihancurkan oleh tentara Belanda sebelum meninggalkan Kabupaten Bengkayang.

Keberadaan Pos Intai van Dering hanya dapat diketahui dari sisa reruntuhan bangunan yang tertutup tanah dan semak belukar. Kondisi tersebut membuat sebagian masyarakat tidak mengetahui keberadaan cagar budaya tersebut. Masyarakat sekitar tidak mengetahui sejarah Benteng van Dering dan bahkan sebagian menganggapnya sebagai benteng peninggalan Jepang. Oleh karenanya, Benteng van Dering merupakan salah satu cagar budaya yang perlu dilestarikan karena merupakan bukti sejarah penjajahan di Kalimantan.

Revitalisasi dan pengelolaan Benteng van Dering oleh pemerintah dapat dilakukan dengan memberdayakan kelompok masyarakat setempat. Beberapa kelompok masyarakat yang dapat dilibatkan adalah Kelompak Masyarakat Sadar Wisata (Pokdarwis) dan Badan Usaha Milik Desa (BUMDes). Kelompok tersebut dapat bekerjasama dengan Bidang Kebudayaan Dinas Pendidikan dan Kebudayaan, Dinas Pariwisata, kementerian terkait, maupun Lembaga Swadaya Masyarakat (LSM), baik nasional maupun internasional.

Pengelolaan Benteng van Dering dapat membawa dampak yang baik bagi masyarakat Kabupaten Bengkayang. Cagar budaya tersebut dapat menjadi ikon daerah serta sebagai bukti sejarah perjuangan bangsa dalam merajut persatuan dan kesatuan atas pengorbanan para pejuang kemerdekaan. Peran serta lintas sektoral sangat diperlukan agar pengelolaan peninggalan bersejarah tersebut dapat dilestarikan. Upaya tersebut dapat dilakukan dengan bekerjasama dengan perguruan tinggi yang terdapat di Kabupaten Bengkayang seperti Perguruan Tinggi Shanti Bhuana, Akademi Keperawatan Bethesda Serukam, Akademi Manajemen Bumi Sebalo, serta beberapa perguruan tinggi keagamaan di Kabupaten Bengkayang.

Terdapat satu pos intai yang dirusak oleh tentara Belanda sebelum meninggalkan Kabupaten Bengkayang. Kondisi tersebut diperparah dengan rendahnya kepedulian pemerintah daerah untuk melakukan revitalisasi maupun pemugaran agar dapat menjadi cagar wisata sejarah yang sangat berharga bagi bangsa Indonesia khususnya Kabupaten Bengkayang. Salah satu upaya yang dapat dilakukan adalah pembuatan papan penunjuk arah serta pembuangan rumput atau semak belukar yang menutupi keberadaan Pos Intai van Dering (Lenti, Beni, Sadewo, \& Usman, 2020).

Pengunjung Benteng van Dering pada umumnya adalah masyarakat yang melewati jalan sekitar bukit. Namun demikian, sebagian masyarakat sengaja datang untuk melihat keberadaan pos intai, terutama anak muda di sekitar Dusun Serukam dan Sungai Betung. Sebagian masyarakat menggunakan pos intai tersebut sebagai tempat singgah sementara 


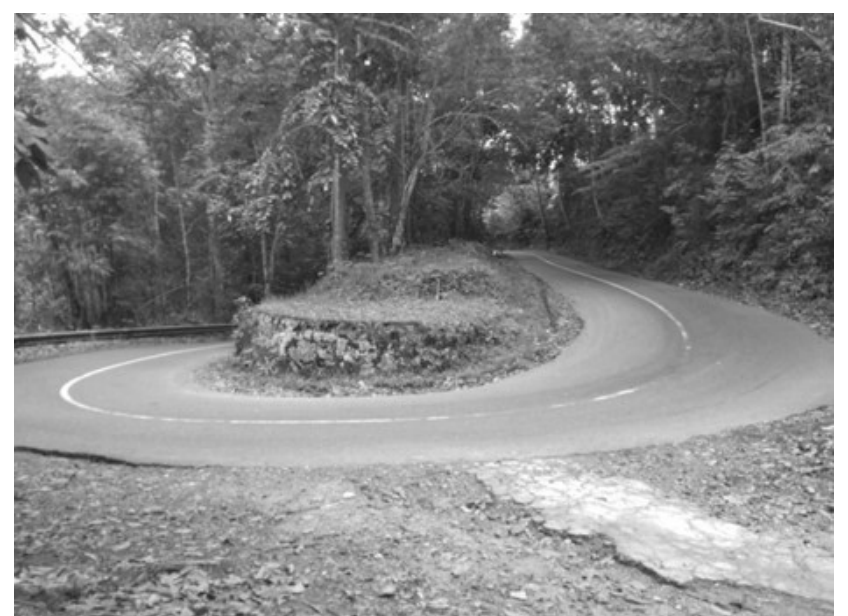

Gambar 1.

Pemandangan Jalan di Sekitar Van Dering Sumber: Dokumentasi Penelitian, 2019

selama menempuh perjalanan. Sementara itu, sebagian yang lain mengunjungi Benteng van Dering karena penasaran atau sedang berkunjung ke salah satu penduduk yang tinggal di kaki bukit.

Pos Intai van Dering terletak di lokasi yang strategis karena tepat berada di atas jalan yang berkelok dengan pemandangan yang sangat menarik. Jalan tersebut berada di kawasan perbukitan dengan kondisi hutan yang masih alami dan sangat dekat dengan Dusun Serukam. Selain itu, terdapat Rumah Sakit Bethesda yang dikenal memiliki pelayanan kesehatan yang berkualitas dan misionaris Protestan yang pada zaman dahulu terkenal hingga Serawak, Malaysia. Berdasarkan latar belakang tersebut, rumusan tujuan penelitian adalah untuk mengetahui tentang upaya revitalisasi pos intai Belanda yang dilakukan oleh pemerintah Kabupaten Bengkayang dalam mengembangkan kawasan Bukit van Dering sebagai daerah wisata sejarah.

\section{TINJAUAN PUSTAKA}

Wisata dapat diartikan sebagai tour menurut bahasa Inggris. Secara etimologi, tour berasal dari kata torah (Ibrani) yang berarti belajar, sementara dalam bahasa Latin terdapat kata tornus yang bermakna alat untuk membuat lingkaran. Bahasa Perancis kuno juga mengenal kata tour yang berarti mengelilingi. Revitalisasi merupakan upaya yang dilakukan untuk menghidupkan kembali suasana suatu ca- gar budaya dengan penyesuaian yang tidak bertentangan dengan prinsip dan nilai dari cagar budaya (NN, 2017).

Peraturan Daerah Kabupaten Bengkayang Nomor 9 Tahun 2014 tentang Kepariwisataan mengartikan industri pariwisata sebagai kumpulan usaha pariwisata yang saling terkait dalam rangka menghasilkan barang dan/atau jasa bagi pemenuhan kebutuhan wisatawan dalam penyelenggaraan pariwisata yang meliputi daya tarik wisata, kawasan pariwisata, dan lainnya. Daya tarik wisata tersebut dapat diartikan usaha yang kegiatannya mengelola daya tarik wisata alam, daya tarik wisata budaya, dan daya tarik wisata buatan/ binaan manusia meliputi usaha mengelola daya tarik wisata alam, usaha mengelola daya tarik budaya, dan usaha mengelola daya tarik wisata buatan (Usman \& Hapsari, 2020).

Kepariwisataan diselenggarakan dengan tujuan: a) mendorong pertumbuhan dan produktivitas ekonomi daerah untuk menyejahterakan masyarakat; b) mengoptimalkan pemanfaatan sumber daya alam, lingkungan, sumber daya manusia beserta hasil budaya, dan produk inovasinya dalam meningkatkan citra dan daya saing daerah di tingkat global; dan c) mengukuhkan jati diri, rasa cinta tanah air, serta kesatuan bangsa dalam membangun persahabatan antardaerah dan bangsa. Penelitian oleh Pristawasa \& Wayan (2017) tentang pengembangan sebuah kampung/dusun adat bernama Saribu Rumah Gadang sebagai tujuan wisata dengan lokasi di Solok Selatan menyimpulkan bahwa pemahaman masyarakat tentang pengembangan pariwisata masih lemah serta dukungan pemerintah yang belum optimal.

Selanjutnya Wirajuna \& Supriadi (2017) dalam penelitiannya tentang peran Kelompok Sadar Wisata (Pokdarwis) menunjukkan bahwa Pokdarwis sangat berperan dan mempunyai pengaruh terhadap pengembangan pariwisata melalui aktivitas monitoring. Keterlibatan Pokdarwis juga dapat menumbuhkan rasa aman bagi para wisatawan yang berkunjung. Penelitian lain tentang peran ekowisata terhadap masyarakat menunjukkan bahwa keberadaan ekowisata terbukti meningkatkan kesejahteraan masyarakat (Wirajuna \& Supriadi, 2017). 
Pengembangan pariwisata memerlukan berbagai upaya, baik melalui sosialisasi maupun peningkatan kesadaran dari semua pihak yang yang terlibat. Semua pihak yang terlibat diharapkan bekerja sama untuk saling melengkapi kekurangan pengelolaan destinasi wisata. Segala upaya tersebut diharapkan dapat meningkatkan jumlah kunjungan wisata (Koentjaraningrat, 2004).

Selanjutnya, Dinas Pariwisata Kabupaten Bengkayang perlu mengembangkan inovasi dengan mengembangkan desa wisata, menghubungkan akses baru ke pengetahuan, dan menyediakan dana khusus. Tujuan tersebut dapat dicapai melalui kerjasama Pokdarwis dengan universitas. Kerjasama tersebut diharapkan dapat membuka akses pengetahuan dan pengalaman kepada semua kelompok. Studi banding mungkin dapat menjadi pilihan tepat untuk mempercepat pemahaman warga daripada pelatihan (Sadewo, Purnasari, \& Dimmera, 2019). Ramadhani (2015) mengemukakan pentingnya integrasi kearifan lokal dalam pengembangan wisata. Nilai kearifan lokal seharusnya tertuang dalam anggaran dasar dan anggaran rumah tangga (AD/ART). Selain itu, pengembangan pariwisata juga terkait dengan penyediaan aksesibilitas, fasilitas wisata, fasilitas umum, pelayanan, promosi, ciri khas yang menjadi daya tarik wisata, serta jaminan keamanan.

Undang-Undang Nomor 11 Tahun 2010 menyatakan bahwa definisi cagar budaya adalah warisan budaya bersifat kebendaan, yaitu berupa kawasan cagar budaya darat dan/atau air yang harus dilestarikan karena bernilai bagi sejarah iptek dan budaya yang telah dilakukan penetapan oleh pemerintah baik berupa situs, bangunan, benda, maupun struktur cagar budaya. Sementara itu, benda cagar budaya adalah benda yang terjadi secara alami ataupun hasil buatan manusia baik yang bisa dipindahkan maupun yang tidak bisa dipindahkan yang memiliki sejarah manusia dan peradabannya.

Pada umumnya, masyarakat mengartikan wisata sebagai rekreasi atau jalan-jalan ke tempat wisata, baik wisata alam, wisata pantai, wisata desa, wisata kota, dan wisata lainnya yang menyediakan pemandangan ataupun atraksi yang tidak ditemui di lingkungan sekitar tempat tinggal. Menurut Suyitno dikutip oleh Beni, Manggu, \& Sensusiana (2018), wisata diartikan sebagai sebuah perjalanan, tetapi tidak semua perjalanan yang dilakukan oleh setiap masyarakat dapat dikatakan sebagai kegiatan berwisata.

Wisata sejarah merupakan salah satu jenis aktivitas wisata yang dapat dijadikan sebagai sarana belajar sekaligus berekreasi yang dapat dinikmati oleh setiap warga masyarakat (Siahaan, Vuspitasari, \& Deffrinica, 2021). Menikmati potensi pariwisata, baik yang masih alami (belum tersentuh oleh kegiatan manusia) maupun yang telah mendapatkan campur tangan manusia (pengelola) dapat memberikan efek kepuasan (Beni \& Manggu, 2017). Selain kepuasan secara jasmani dan rohani, para wisatawan akan mendapatkan tambahan pengetahuan dan pengalaman yang menjadikan inspirasi serta rasa cinta terhadap alam semesta sebagai anugerah ciptaan Tuhan Yang Maha Esa (Beni \& Rano, 2017).

Kemiskinan menurut Soekamto dalam Beni \& Rano (2017) dianggap sebagai masalah sosial yang sering terjadi di masyarakat karena ketidaksesuaian beberapa unsur yang terdapat di tengah masyarakat yang dapat mengancam kehidupan sosial masyarakat. Masalah-masalah sosial biasanya dapat atau sering muncul karena adanya perbedaan-perbedaan yang sangat signifikan antara nilai yang dianut masyarakat dengan keadaan yang terjadi di tengah masyarakat. Hal tersebut bertolak belakang dengan keadaan dan hakikat kelahiran manusia, yaitu untuk bahagia, sejahtera, makmur, dan sukses (Vuspitasari \& Ewid, 2020).

\section{METODE PENELITIAN}

Penelitian ini menggunakan pendekatan kualitatif. Bogdan \& Tailor dalam Moleong (2000) mendefinisikan penelitian kualitatif sebagai prosedur yang dilakukan dalam penelitian untuk menghasilkan data dan fakta di lapangan yang dideskripsikan berupa kalimat atau tulisan tentang masyarakat serta perilaku yang terjadi di lapangan. Data penelitian didapatkan melalui kunjungan lapangan dan wawancara terhadap para pemangku kepentingan yang dapat dipercaya dan telah divalidasi. Narasumber penelitian adalah tetua adat setempat, aparatur Dusun Serukam dan Desa Pasti Jaya, Pemerintah Kecamatan Samalantan, dan penduduk setempat. Fokus penelitian ini adalah upaya kegiatan revitalisasi cagar budaya sejarah Benteng van Dering, Serukam. 
Data yang digunakan adalah data primer dan data sekunder. Data primer diperoleh dari wawancara terhadap para tetua adat setempat, kepala desa, pemerintah kecamatan, serta penduduk setempat. Data primer juga diperoleh melalui observasi di pos intai dan kawasan Bukit van Dering. Sementara itu, data sekunder diperoleh dari Dinas Pariwisata serta Badan Pengelolaan Keuangan dan Aset Daerah Pemerintah Kabupaten Bengkayang. Data yang diperoleh selanjutnya dibandingkan dengan literatur dan hasil penelitian terdahulu yang relevan. Analisis data dilakukan secara kualitatif dengan mendeskripsikan data penelitian untuk menjawab pertanyaan penelitian.

\section{HASIL DAN PEMBAHASAN}

\section{Profil Wilayah Bukit van Dering}

Bukit van Dering merupakan salah satu wilayah di Kecamatan Samalantan, Kabupaten Bengkayang, Kalimantan Barat. Kecamatan ini terletak di barat daya Kabupaten Bengkayang. Tidak jauh dari kantor kecamatan, berdiri sebuah tugu perdamaian suku Dayak dengan suku Madura. Hal tersebut menandakan kecamatan ini menjadi salah satu saksi bisu dari konflik Sampit yang terjadi di tahun 1997.

Secara astronomis, Kecamatan Samalantan berada pada $0^{\circ} 42^{\prime} 42^{\prime \prime}$ LU hingga $1^{\circ} 03^{\prime} 14^{\prime \prime}$ LU dan $109^{\circ} 07^{\prime} 98^{\prime \prime}$ BT hingga $109^{\circ} 23^{\prime} 14^{\prime \prime}$ BT. Secara administratif, Kecamatan Samalantan berbatasan langsung dengan Kecamatan Lembah Bawang di sebelah utara, Kabupaten Landak di sebelah selatan, Kecamatan Sungai Betung di sebelah timur, dan Kecamatan Monterado di sebelah barat.

Dusun Serukam yang berada di wilayah Kecamatan Samalantan memiliki luas wilayah sebesar $420,5 \mathrm{~km}^{2}$ atau sekitar 7,79\% dari keseluruhan luas Kabupaten Bengkayang. Kecamatan Samalantan terbagi menjadi tujuh desa, yaitu Desa Sabau, Desa Tumiang, Desa Pasti Jaya, Desa Baban, Desa Bukit Serayan, Desa Marunsu, dan Desa Samalantan. Bukit van Dering berada di wilayah Desa Pasti Jaya tepatnya di sebuah dusun bernama Serukam. Dusun tersebut berada di kaki Bukit van Dering yang dikelilingi perbukitan serta alam yang masih asri. Dusun Serukam sudah dikenal sejak masa penjajahan hingga kemerdekaan karena keberadaan sebuah rumah sakit milik yayasan
Protestan yaitu Rumah Sakit Bethesda. Selain itu, terdapat sebuah landasan pacu untuk pesawat capung.

\section{Pelaksanaan Revitalisasi}

Berdasarkan data yang ditemukan dan dokumen dari Pemerintah Kabupaten Bengkayang melalui Dinas Pendidikan dan Kebudayaan bahwa status Pos Intai van Dering masih dalam status Objek Diduga Cagar Budaya (ODCB). Status ini perlu diperjelas oleh Kementerian Pendidikan dan Kebudayaan agar keberadaan pos intai tersebut dapat segera dilakukan aksi nyata dalam upaya pelestariannya melalui penganggaran dana kegiatan revitalisasi.

Berdasarkan hasil kunjungan dan pengamatan di Pos Intai van Dering dapat dinyatakan bahwa kegiatan revitalisasi di Benteng van Dering belum dilakukan secara optimal. Selama ini, pemilik lahan di sekitar Pos Intai van Dering belum melakukan upaya pemugaran secara swadaya. Upaya tersebut juga belum dilakukan oleh Pemerintah Desa Pasti Jaya, Pemerintah Kecamatan Samalantan, bahkan Pemerintah Kabupaten Bengkayang. Kondisi di lapangan juga menunjukkan tidak ada lampu penerangan di sekitar pos intai sehingga pada saat malam, kondisi pos intai menjadi gelap gulita dan memberikan kesan angker serta menambah ketidaktahuan warga terhadap informasi keberadaannya.

Berdasarkan hasil wawancara dengan pemilik lahan tempat berdirinya salah satu pos intai yang masih bisa dikunjungi mengatakan bahwa belum ada perbaikan berarti yang dilakukan oleh pemerintah. Perbaikan yang pernah dilakukan oleh Pemerintah Kabupaten Bengkayang dilakukan sekitar tahun 1990 dengan membuat atap di atas pos intai dan meletakkan kursi di atasnya. Saat ini, kursi tersebut telah dirobohkan oleh orang yang tidak dikenal karena dianggap mengganggu estetika pos intai. Keberadaan kursi tersebut menjadikan kawasan wisata pos intai menjadi tidak asri karena dijadikan tempat berkumpul para remaja.

Wawancara dengan Pemerintah Kabupaten Bengkayang menyatakan pemerintah belum memiliki rencana untuk merevitalisasi dan mengelola Benteng van Dering sebagai salah satu wisata cagar budaya. Belum adanya 


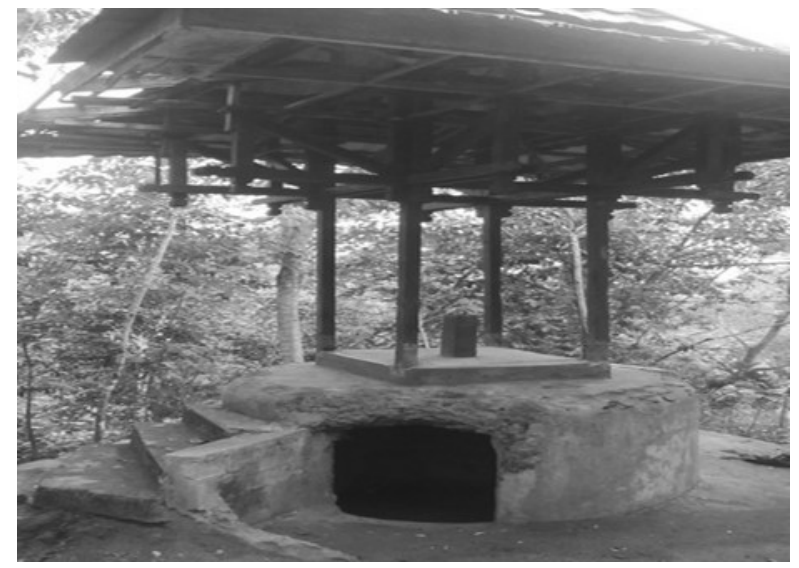

Gambar 2.

Kondisi Pos Intai van Dering

Sumber: Dokumentasi Penelitian, 2019

perhatian dari Pemerintah Kabupaten Bengkayang menjadikan cagar budaya tersebut berada pada kondisi memprihatinkan. Atap yang berada di atas pos intai sudah mulai lapuk. Selain itu, beberapa bagian bangunan juga sudah rusak. Gambar 2 merupakan kondisi terkini dari pos intai yang tidak terjaga serta di sekitarnya terdapat banyak sampah dan bekas pembakaran yang sangat mengganggu pemandangan dan estetika dari keberadaan pos intai tersebut.

Pemerintah Kabupaten Bengkayang belum mengalokasikan anggaran untuk revitalisasi Pos Intai van Dering karena keterbatasan anggaran. Selain itu, masih terdapat ketidakjelasan kewenangan pengelolaan antara pemerintah pusat dan pemerintah daerah. Pemerintah Kabupaten Bengkayang berharap pemerintah pusat dapat segera menetapkan perubahan status Benteng van Dering dari Objek Diduga Cagar Budaya (ODCB) menjadi situs cagar budaya dan segera melakukan kegiatan revitalisasi.

Kondisi jalan menuju pos intai dari jalan raya dapat dilihat pada gambar 3. Pemerintah daerah sudah pernah melakukan perbaikan jalan setapak dari jalan raya menuju pos intai. Namun demikian, perbaikan yang dilakukan kurang memadai sehingga cenderung licin ketika musim penghujan. Kurangnya perhatian dari pemerintah membuat pemilik lahan (Bapak Misae) di lokasi pos intai berinsiatif membangun sebuah rumah. Rumah tersebut berlokasi di bawah Pos Intai van Dering. Pemilik lahan berharap rumah tersebut dapat menjadi

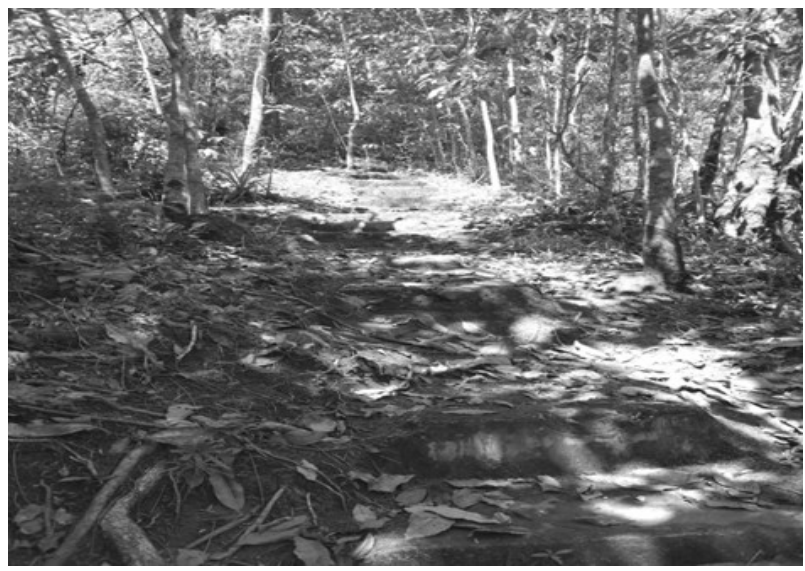

Gambar 3.

Kondisi Jalan Menuju Pos Intai van Dering Sumber: Dokumentasi Penelitian, 2019

penunjuk arah keberadaan Pos Intai van Dering. Selain itu, pemilik lahan juga berharap pemerintah memberikan perhatian sehingga melakukan perbaikan cagar budaya tersebut. Pemilik lahan menganggap keberadaan pos intai tersebut memiliki arti penting dalam sejarah perjuangan bangsa Indonesia, khususnya penduduk Serukam.

Sementara itu, berdasarkan telaah dokumen perencanaan dari Dinas Pariwisata maupun Dinas Pendidikan dan Kebudayaan, menunjukkan bahwa Pemerintah Kabupaten Bengkayang belum memiliki rencana revitalisasi Benteng van Dering. Hal tersebut dapat berdampak negatif bagi pemerintah daerah, masyarakat, serta perkembangan ilmu pengetahuan. Rusaknya benda-benda cagar sejarah menjadikan informasi berkaitan dengan masa penjajahan Belanda di Kalimantan semakin terbatas.

Apabila dikelola dengan baik, Pos Intai van Dering dapat menjadi sebuah ikon wisata sejarah. Selanjutnya, hal tersebut dapat berdampak terhadap peningkatan pendapatan asli daerah. Benteng van Dering juga dikelilingi oleh panorama alam yang sangat indah berupa bukit yang sejuk dan rindang. Oleh karenanya, Kawasan van Dering tidak hanya menawarkan wisata sejarah melainkan juga wisata alam. Selain itu, di Dusun Serukam terdapat RS Bethesda yang juga sudah terkenal hingga luar negeri. Hasil penelitian menemukan bahwa kegiatan revitalisasi Pos Intai van Dering Serukam dapat dilakukan melalui beberapa tahap. 


\section{Pedoman Revitalisasi}

Kemendikbud melalui Direktorat Pelestarian Cagar Budaya dan Permuseuman menyusun Pedoman Revitalisasi Cagar Budaya di tahun 2013. Berdasarkan pedoman tersebut, revitalisasi ditujukan untuk menumbuhkan kembali nilai-nilai penting cagar budaya dengan penyesuaian fungsi ruang baru yang tidak bertentangan dengan prinsip pelestarian dan nilai budaya masyarakat. Revitalisasi cagar budaya tidak hanya dilakukan oleh Kementerian Pendidikan dan Kebudayaan, tetapi juga dilakukan oleh kementerian lainnya. Selain itu, revitalisasi juga dapat dilakukan oleh masyarakat dan hukum adat, swasta, komunitas, serta lembaga swasta.

Berdasarkan pedoman revitalisasi, pemerintah daerah sebaiknya mengambil tindakan yang harus lebih maju dalam melakukan revitalisasi. Sekarang ini, revitalisasi dapat dilakukan dengan dukungan pemerintah pusat melalui dana desa yang dapat dikelola oleh Badan Usaha Milik Desa (BUMDes). Kekayaan daerah yang bernilai tinggi dapat dikembangkan dengan aturan yang jelas serta membawa dampak yang sangat luar biasa bagi kemakmuran masyarakat serta kemajuan daerah.

\section{Kerjasama dengan Perguruan Tinggi}

Kerjasama antara pemerintah dengan perguruan tinggi merupakan langkah strategis dalam kegiatan revitalisasi. Selain itu, kerjasama tersebut juga dapat dimaknai sebagai dukungan pemerintah daerah terhadap kehadiran perguruan tinggi di daerah. Dukungan perguruan tinggi diwujudkan dalam kegiatan penelitian dan kajian yang dapat menjadi masukan dalam merencanakan revitalisasi. Oleh karenanya, kegiatan revitalisasi dapat berjalan efektif serta searah dengan pengembangan pariwisata budaya. Selanjutnya, kegiatan revitalisasi dapat menumbuhkan pariwisata daerah sehingga bermanfaat bagi masyarakat sekitar maupun Pemerintah Kabupaten Bengkayang.

Salah satu tujuan revitalisasi adalah untuk kemaslahatan masyarakat. Keberadaan perguruan tinggi di Kabupaten Bengkayang khususnya program studi kewirausahaan dapat menjadi inisiator bagi masyarakat untuk mengelola potensi sumber daya alam di Bukit van Dering melalui kegiatan wirausaha sehing- ga dapat memajukan kehidupan ekonomi masyarakat di sekitar Benteng van Dering.

\section{Pembenahan Infrastruktur}

Pembenahan infrastrukur dilakukan dengan terlebih dahulu memperbaiki kondisi jalan raya baik dari arah Kabupaten Bengkayang menuju Kabupaten Singkawang maupun sebaliknya. Saat ini, jalan tersebut berada pada kondisi rusak dengan beberapa bagian ditemukan jalan berlubang. Pembenahan infrastruktur tersebut dapat dilakukan oleh pemerintah provinsi karena jalan tersebut merupakan penghubung antarkabupaten.

Selain perbaikan jalan raya, jalan menuju pos intai juga perlu diperbaiki untuk menjamin kenyamanan dan keamanan pengunjung. Kondisi saat ini, jalan setapak menuju pos intai cenderung licin, terutama setelah hujan. Selain itu, di jalan tersebut dapat ditambahkan pegangan atau pagar di bagian sisi untuk mencegah pengunjung tergelincir atau jatuh.

\section{Literasi}

Literasi merupakan upaya mendokumentasikan. Literasi dapat dilakukan dengan membuat dokumen cetak yang memuat informasi tentang keberadaan Pos Intai van Dering. Hal tersebut dilakukan agar masyarakat maupun pelajar dengan mudah dapat mengakses pos intai tersebut. Selain itu, upaya literasi dapat dilakukan secara manual maupun digital. Kegiatan tersebut dapat dilakukan oleh pemerintah daerah dengan menganggarkan dana penerbitan buku sebagai materi muatan sejarah dan adat budaya lokal. Buku tersebut dapat diajarkan di sekolah-sekolah yang ada di Kabupaten Bengkayang.

Pemerintah Kabupaten Bengkayang telah melakukan kegiatan literasi dengan bekerja sama dengan perguruan tinggi di Kabupaten Bengkayang. Kerjasama tersebut terwujud dengan menerbitkan buku tentang Pos Intai van Dering serta pembuatan website ataupun promosi melalui media elektronik. Kegiatan literasi juga dapat dilakukan dengan menyediakan papan informasi di lokasi wisata yang mudah diakses oleh pengunjung. Papan informasi sebaiknya memuat sejarah keberadaan pos intai dan ditampilkan dalam bahasa yang efektif dan mudah dipahami. 


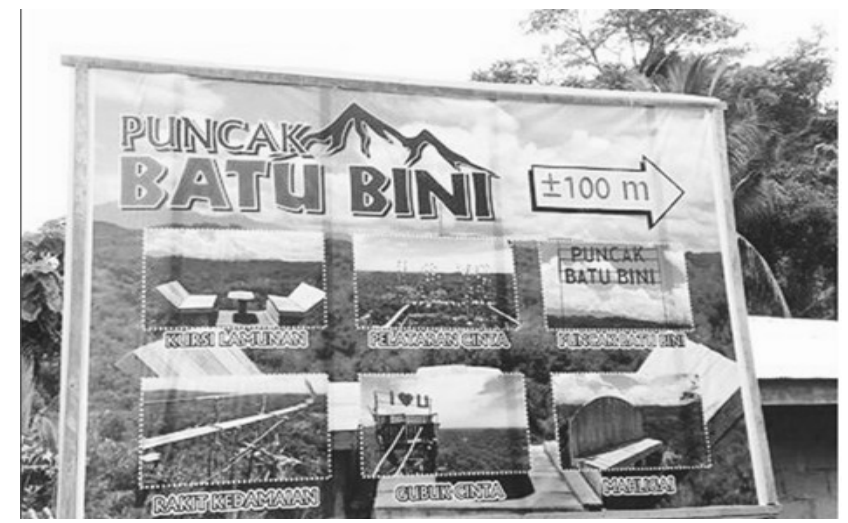

Gambar 4.

Contoh Petunjuk Arah

Sumber : http://asli-urang-

banua.blogspot.com/2017wisata-kekinian-hulu-sungai

Selain pembuatan papan literasi, Pos Intai van Dering juga perlu dilengkapi dengan papan penunjuk arah. Seperti contoh pada gambar 4 . Papan tersebut dapat diletakkan di sekitar jalan di kawasan Bukit Van Dering baik dari arah Bengkayang menuju Singkawang ataupun sebaliknya. Selain sebagai sumber informasi keberadaan pos intai, papan tersebut juga berfungsi sebagai sarana promosi keberadaan destinasi wisata di sekitar jalan tersebut. Pembuatan papan penunjuk arah juga diharapkan dibuat dengan standar yang memadai. Papan penunjuk tersebut dapat mencantumkan gambar pos intai serta dilengkapi lampu penerangan agar saat malam hari dapat diketahui dan terlihat oleh masyarakat yang melewati jalan di Bukit Van Dering. Langkah-langkah tersebut perlu segera dilakukan oleh pemerintah daerah sambil menunggu kebijakan pemerintah pusat.

\section{Pemugaran}

Kegiatan pemugaran dilakukan untuk mengembalikan kondisi fisik cagar budaya. Tujuan dilaksanakan pemugaran untuk mengembalikan kondisi fisik dengan cara memperbaiki, memperkuat, dan/atau mengawetkannya melalui pekerjaan rekonstruksi, konsolidasi, rehabilitasi, restorasi, dan anastilosis.

Kegiatan pemugaran sebaiknya dilakukan dengan melibatkan berbagai pihak terkait yang mengetahui asal usul serta bentuk awal dari pos intai. Hal tersebut dimaksudkan agar tujuan pemugaran tercapai, yaitu menghadirkan kembali kondisi fisik bangunan Pos Intai van
Dering. Tahapan pemugaran sebaiknya dilakukan sesuai dengan tahap pemugaran cagar budaya yang dilakukan oleh Kementerian Pendidikan dan Kebudayaan sebagai berikut:

a) Prapemugaran

Prapemugaran dilakukan terlebih dahulu dengan studi kelayakan pemugaran serta studi teknis dan perencanaan. Tahapan ini diharapkan melibatkan peran perguruan tinggi serta dinas terkait, khususnya Dinas Pendidikan dan Kebudayaan Bidang Kebudayaan serta Dinas Pariwisata Kabupaten Bengkayang;

b) Pemugaran

Proses ini memiliki dua sub-tahapan, yaitu pemulihan arsitektur dan perbaikan struktur. Secara terperinci, proses pemugaran meliputi kegiatan pembongkaran, perkuatan struktur, perawatan bahan, dan penggantian bahan asli. Pemulihan arsitektur adalah pengembalian keaslian bentuk benda cagar budaya sesuai awal pendiriannya atau ketika pertama kali ditemukan. Subtahapan tersebut melibatkan aktivitas pemasangan unsur bangunan asli yang dibongkar, pemasangan unsur bangunan baru pengganti, dan pemasangan unsur bangunan asli temuan;

c) Pascapemugaran

Kegiatan dalam pasca-pemugaran adalah penataan lingkungan situs yang bertujuan untuk melindungi/memelihara kelestarian cagar budaya dan pemanfaatannya. Tata cara penataan lahan diawali dengan melakukan kajian terhadap kondisi topografi dan keterawatan lingkungan di sekitar bangunan cagar budaya. Selanjutnya langkah-langkah lain dapat dilakukan dalam rangka pengembangan dan pemanfaatannya. Proses pelaksanaannya dilakukan melalui serangkaian kegiatan yang mencakup penataan halaman, pengadaan sarana dan fasilitas, serta pembuatan taman. Penataan halaman merupakan kegiatan dalam rangka mempersiapkan lahan situs untuk menunjang pemeliharaan dan pemanfaatan. Kegiatannya meliputi pembersihan halaman, pematangan tanah, perkuatan struktur tanah dengan memperhatikan kondisi lahan. 
Rekonstruksi adalah upaya pemulihan bangunan yang kegiatannya menitikberatkan pada pengembalian keaslian bentuk bangunan dengan penambahan bahan baru. Revitalisasi Pos Intai van Dering sebaiknya dilakukan dengan memulihkan kondisi bangunan seperti semula terutama pada pos intai yang rusak berat serta area parit yang menjadi penghubung antarpos intai. Selain itu, pembuatan papan penunjuk arah juga perlu dilakukan untuk memberikan informasi tentang keberadaan pos intai tersebut.

Konsolidasi adalah upaya perbaikan bangunan yang kegiatannya menitikberatkan pada upaya memperkuat atau memperkokoh berdirinya bangunan. Kegiatan konsolidasi pada pos intai dapat dilakukan dengan memperbaiki bangunan pos intai yang sudah lapuk terkena air hujan maupun tertimbun oleh tumbuhan serta penggalian kembali parit-parit penghubung tiap pos intai.

Rehabilitasi adalah upaya perbaikan dan pemulihan bangunan yang kegiatannya menitikberatkan pada penanganan yang sifatnya pemeliharaan. Kegiatan rehabilitasi Pos Intai van Dering dapat dilakukan dengan memperbaiki sarana dan prasarana di sekitar area pos intai terutama jalan raya. Hal tersebut dimaksudkan untuk memudahkan masyarakat dalam mengunjungi kawasan tersebut serta penambahan area wisata dengan membuat papan informasi serta tempat beristirahat bagi pengunjung.

Restorasi adalah upaya pemulihan bangunan yang kegiatannya menitikberatkan pada pengembalian keaslian bentuk bangunan tanpa penggunaan bahan baru. Restorasi dapat dilakukan terhadap beberapa pos intai yang sudah hancur dengan membuatnya berdiri seperti semula. Penggunaan material baru dapat digunakan agar pos intai dapat berdiri kokoh seperti semula.

Anastilosis adalah pemasangan kembali unsur bangunan yang semula runtuh dan berserakan. Anastilosis dilakukan dari hasil susun coba berdasarkan kecocokan atau kesinambungan bentuk, ikatan, dan pola hias masingmasing unsur yang dapat dipertanggungjawabkan secara arkeologis dan arsitektoris. Upaya anastilosis sangat diperlukan untuk merevitalisasi pos intai karena dari beberapa pos intai, hanya terdapat satu unit yang masih berdiri kokoh. Sementara itu, beberapa pos selebihnya sudah hancur karena sengaja dirobohkan oleh Belanda sebelum meninggalkan Indonesia.

\section{Promosi}

Promosi merupakan kegiatan memberikan informasi kepada khalayak ramai tentang sesuatu yang belum diketahui. Melalui promosi, diharapkan orang akan mengetahui dan bermaksud memiliki barang atau mengunjungi tempat yang dipromosikan. Promosi dapat dilakukan secara langsung maupun secara tidak langsung menggunakan cara konvensional maupun digital.

Kegiatan promosi konvensional tentang keberadaan wisata Pos Intai van Dering dapat dilakukan melalui pembuatan petunjuk arah menuju lokasi wisata. Selain itu, promosi juga dapat dilakukan dengan menyampaikan informasi melalui kegiatan seminar, baik tingkat lokal, nasional, maupun internasional. Sementara itu, promosi digital dapat dilakukan dengan penyebarluasan infomasi wisata Pos Intai van Dering melalui media digital. Promosi digital berpeluang lebih efektif untuk menjangkau masyarakat secara lebih luas.

Sekarang ini, kegiatan promosi dapat dengan mudah dilakukan dengan biaya yang lebih sedikit. Namun demikian, upaya promosi hendaknya didahului dengan penyediaan sarana prasarana pendukung wisata. Penggunaan media sosial yang masif membuat destinasi wisata yang menarik dengan mudah tersebar di masyarakat.

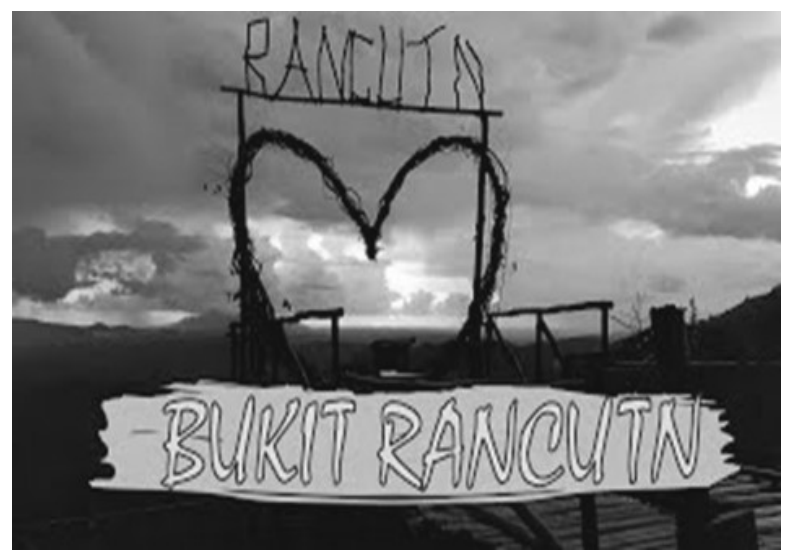

Gambar 5..

Contoh Pesona Pariwisata Bukit Van Dering

Sumber : https://www.youtube.com/watch? $\mathrm{v}=\mathrm{BiC} \_$NMBMfLU, 2020 
Kondisi tersebut terjadi di salah satu kawasan Perbukitan van Dering, yaitu Bukit Rancutn. Seperti pada Gambar 5. Bukit tersebut berada di sekitar Pos Intai van Dering dengan pemandangan yang cukup indah. Destinasi wisata ini juga telah dilengkapi dengan beberapa fasilitas penunjang untuk kenyamanan pengunjung. Sebagai hasilnya, keberadaan destinasi wisata tersebut dengan mudah tersebar di masyarakat melalui peran media sosial.

\section{KESIMPULAN DAN SARAN}

\section{Kesimpulan}

Berdasarkan analisis terhadap data penelitian menunjukkan bahwa Pos Intai van Dering merupakan salah satu bukti sejarah perjuangan masyarakat Bengkayang pada masa penjajahan Belanda. Namun demikian, pemerintah, baik daerah maupun pusat belum memberikan perhatian terhadap pos intai tersebut. Hal tersebut menyebabkan pos intai berada pada kondisi rusak dan tidak terawat. Keberadaan Pos Intai van Dering memiliki arti penting bagi Kabupaten Bengkayang. Selain sebagai cagar budaya, kawasan Pos Intai van Dering dapat dikelola sebagai sebagai salah satu destinasi wisata budaya. Selain itu, Pos Intai van Dering terletak di lokasi yang cukup strategis sehingga potensial untuk dikembangkan. Pengembangan wisata di kawasan tersebut berpotensi meningkatkan pemasukan masyarakat sekitar yang selanjutnya dapat meningkatkan pendapatan asli daerah Kabupaten Bengkayang.

Perhatian yang diberikan pemerintah daerah adalah dengan mengajukan kawasan pos intai sebagai cagar budaya yang saat ini masih berstatus Objek Diduga Cagar Budaya (ODCB). Setelah menjadi cagar budaya, pemerintah diharapkan memberikan perhatian dengan mengalokasikan anggaran untuk kegiatan revitalisasi dan pengeloaan wisata.

\section{Saran}

Saran yang dapat diberikan khususnya kepada Pemerintah Kabupaten Bengkayang melalui dinas terkait adalah menganggarkan dana guna merevitalisasi pos intai yang bernilai sejarah. Pemerintah daerah juga diharapkan dapat mengembangan pos intai tersebut se- bagai salah satu destinasi wisata sejarah dan ikon Kabupaten Bengkayang. Pemerintah daerah diharapkan dapat bekerja sama dengan perguruan tinggi dalam kegiatan literasi dan kajian teknis sebelum melakukan pemugaran. Hal tersebut dimaksudkan supaya tujuan pemugaran dapat tercapai dengan baik serta membawa dampak nyata bagi masyarakat sekitar. Selanjutnya, pemerintah daerah juga dapat melakukan perbaikan infrastrukur terutama akses jalan menuju Pos Intai van Dering. Kendala utama berkaitan dengan infrastruktur adalah kondisi jalan yang licin sera penerangan yang kurang memadai. Langkah terakhir yang dapat dilakukan oleh pemerintah daerah adalah memberdayakan para sarjana pariwisata yang mendapatkan beasiswa dari pemerintah daerah untuk berperan dalam kegiatan revitalisasi dan pengembangan pariwisata Kawasan van Dering.

\section{DAFTAR PUSTAKA}

Beni, S. (2017). Pembangunan Manusia Melalui Pendidikan Dasar Credit Union. Jakarta: Mer-C Publishing.

Beni, S., \& Manggu, B. (2017). Peran Credit Union dalam Bidang Agribisnis untuk Pembangunan Pertanian dan Ekonomi. JURKAMI, 2(2), 103-111. Retrieved from http://jurnal.stkippersada.ac.id/jurnal/ index.php/JPE/article/view/621.

Beni, S., Manggu, B., \& Sensusiana. (2018). Modal Sosial Sebagai Suatu Aspek dalam Rangka Pemberdayaan Masyarakat. JURKAMI, 3(1), 8-24. Retrieved from http://jurnal.stkippersada.ac.id/jurnal/ index.php/JPE/article/view/341.

Beni, S., \& Rano, G. (2017). Credit Union Sebagai Penggerak Ekonomi Masyarakat Dayak Kalimantan Barat. Prosiding International Congress I Dayak Culture, 1, 168-177.

Erbito, Y., \& Hapsari, V. R. (2019). Konsep Pengelolaan Administrasi Menggunakan Sistem Informasi Desa pada Desa Sebente Kabupaten Bengkayang. Business Economic and Entrepreneurship, 1(2), 28-36. Retrieved from www.iranesrd.com. 
Hapsari, V. R., Usman, \& Ayustia, R. (2021). Pengembangan Objek Wisata Alam Sebagai Daerah Tujuan Wisata di Daerah Perbatasan. Maneksi, 9(2), 427-431.

Koentjaraningrat. (2004). Manusia dan Kebudayaan di Indonesia. Jakarta: Djambatan.

Lenti, M., Beni, S., Sadewo, Y. D., \& Usman. (2020). Strategi Diferensiasi Produk LINE untuk Menarik Minat Konsumen. Business Economic and Entrepreneurship, 2(2), 9-19.

NN. (2017). Modul Pelestarian Bangunan Gedung. Semarang: Kementerian PU.

Pristawasa, \& I Wayan, T. (2017). Motivasi dan Persepsi Wisatawan Terhadap Potensi Wisata di Kepulauan Mentawai. Jurnal Kepariwisataan dan Hospitalitas, 1(2), 111- 177.

Purnasari, P. D., \& Sadewo, Y. D. (2019). Pendidikan Kewirausahaan Berbasis Ketahanan Nasional dan Budaya Amare. Seminar Nasional Kesadaran Bela Negara dalam Rangka Mencegah Disintegrasi Bangsa di Era Revolusi Industri, 64-70.

Ramadhani, A. R. (2015). Analisis Potensi Pendapatan Asli Daerah di Provinsi Kalimantan Tengah Tahun 2009-2014 (Thesis). Malang: Universitas Muhammadiyah.

Sadewo, Y. D., \& Purnasari, P. D. (2019). Peran Self Efficacy Terhadap Kemampuan Berwirausaha Mahasiswa STIM Shanti Bhuana. Business Economic and Entrepreneurship, 1(1), 32-38.

Sadewo, Y. D., Purnasari, P. D., \& Dimmera, B. G. (2019). Pendidikan Kewirausahaan Berbasis Ketahanan Nasional dan Budaya Amare. Makasar: Tohar Media.

Siahaan, S. V., Vuspitasari, B. K., \& Deffrinica. (2021). Menggali Peluang Ekonomi Kreatif Melalui Potensi Desa (Studi Kasus Desa Suka Maju Kecamatan Sungai Betung Kabupaten Bengkayang). Sebatik, 25(1).
Usman, \& Hapsari, V. R. (2020). Menggali Potensi Mahasiswa dalam Meningkatkan Semangat Kewirausahaan di Daerah Perbatasan. Business Economic and Entrepreneurship, 1(2), 24-31.

Vuspitasari, B. K., \& Ewid, A. (2020). Peran Kearifan Lokal Kuma Dalam Mendukung Ekonomi Keluarga Perempuan Dayak Benyadu. Sosiohumaniora, 22(1), 26-35.

Wirajuna, B., \& Supriadi, B. (2017). Peranan Kelompok Sadar Wisata untuk Meningkatkan Keamanan Wisatawan: Studi Kasus di Jerowaru Nusa Tenggara Barat. Pariwisata Pesona, 2(2), 15-25.

\section{BIODATA PENULIS}

Sabinus Beni lahir 16 Juli 1984 di Dusun Jambu, Desa Semirau, Kecamatan Jangkang, Kabupaten Sanggau, Provinsi Kalimantan Barat. Gelar Sarjana Pertanian diperoleh dari Program Studi Agroteknologi dan Magister Ilmu Ekonomi dari Universitas Tanjungpura Pontianak. Saat ini bekerja sebagai tenaga pengajar di Program Studi Kewirausahaan, Institut Shanti Bhuana Bengkayang, Provinsi Kalimantan Barat.

Blasius Manggu, Lahir di Karot (NTT) 12 Oktober 1970. Lulusan S1 Akuntansi STIE Y.A.I Jakarta dan Magister Manajemen Universitas Bhayangkara Jakarta Raya. Dosen Program Studi Manajemen Institut Shanti Bhuana, Bengkayang, Kalimantan Barat.

Yosua Damas Sadewo, Lahir di Wonosobo (Jateng) 24 Juni 1990. Menyelesaikan S1 PGSD dan Magister Manajemen Pendidikan Univ. Kristen Satya Wacana Salatiga. Dosen Program Studi PGSD Institut Shanti Bhuana, Bengkayang, Kalimantan Barat.

Tomas Aquiono, Lahir di Pemangkat (Kalbar) 28 Januari 2000. Mahasiswa Program Studi Kewirausahaan. 